\section{Temporal Patterning of Post-Pleistocene Glaciation}

Most post-Pleistocene glaciation has apparently been confined to four phases at intervals of around 2,600 years ${ }^{1}$. The exact timing of these phases will be examined in relation to recent carbon-14 age corrections and additional glacial chronologies.

The earliest glacial phase, the Cochrane-Cockburn, occurred in North America and has been dated by ${ }^{14} \mathrm{C}$ methods at around 8,000 9,000 years BP, probably nearer 8,000 years BP (ref. 2). The correlation of the CochraneCockburn glacial phase with Swiss $^{3}$, Austrian ${ }^{4}$ and Swedish $^{5}$ glaciation is still uncertain. The second phase, the Atlantic/sub-Boreal transition, is now well documented from North America ${ }^{6-9}$ and from Europe ${ }^{5,6,10}$ as occurring around 4,500-5,000 ${ }^{14} \mathrm{C}$ years $\mathrm{BP}$ and culminating between 4,600-4,800 years BP. The third phase, the subAtlantic minimum, culminated around $2,600-2,800{ }^{14} \mathrm{C}$ years BP in North America ${ }^{1,7}$ and in Europe ${ }^{1,4,7,11,12}$ and probably in Australia" . The last phase, the "Little Ice Age", had a world-wide culmination around AD 1,550 1,900 (ref. 1) which was synchronous for North America, Arctic-Eurasia and the Southern Hemisphere.

The mid-points of the culmination of these four glacial phases were 8,000 (tentatively), 4,700 and $2,700^{14} \mathrm{C}$ years BP and 225 years BP. Studies of conversion of ${ }^{14} \mathrm{C}$ to true time ${ }^{14,15}$ indicate that from $0-2,500 \mathrm{BP},{ }^{14} \mathrm{C}$ and true time were the same; $2,500-5,500{ }^{14} \mathrm{C}$ years $\mathrm{BP}$ there was an underestimate of true time; and around $8,000 \mathrm{BP},{ }^{14} \mathrm{C}$ and true time were, again, about the same. Correction factors of 1.03 for $2,700 \mathrm{BP}$, of $1 \cdot 14$ for $4,700 \mathrm{BP}$ and of 1.03 for 8,000 BP were estimated (from ref. 15) to give corrected dates of $8,250,5,350$ and $2,780 \mathrm{BP}$. These dates, together with the recent date of $225 \mathrm{BP}$, give intervals of 2,900 , 2,570 and 2,555 , of which the first is not very reliable. Neglecting the first interval, the last three glacial phases are separated by around 2,600 years. An arithmetic progression starting with 22 years (the complete sunspot eycle) and a first term of four results in a sequence of 88,440 and 2,640 years. The estimate of an 11 year half cycle is based on the mean length of 11.04 years for 214 BC-AD 1382 and 1830-1957 (ref. 16) and neglecting the interval 1382-1830 as a sunspot dearth period.

The apparent cyclic recurrence of the four glacial phases and, with the possible exception of the first phase, their synchronism in Europe, North America and elsewhere, suggest they have a similar cause. The most likely explanation of the recent glacial phase was lower temperature and a shorter ablation season ${ }^{17,18}$. If all four phases were caused by a periodic decline in temperature, then the decline would have been modified by the chief trend in temperature during the Holocene, because there is a decreased severity of glaciation from the first to second phase and an increased severity to the third and fourth phase. This pattern may reflect a periodic temperature decline which was of decreasing expression as a result of the predominant rising temperature of the early to mid. Holocene, and of increasing expression as a result of the subsequent temperature decline following the Thermal Maximum. Tho periodic appearance of glacial phases throughout the Holocene and their occurrence near the Thermal Maximum suggest that the mechanism underlying these phases is independent of that determining the predominant Holocene temperature trend.

There secm to be two major Holocene temperature patterns: (1) the predominant trend of increase in temperature followed by a slight decrease, exemplified by retreat of Pleistocene ice and the subsequent renewal of alpine glaciation and by the rapid rise and later fall in ocean level; and (2) a secondary trend of recurrent cold phases with greatly increased glaciation at higher altitudes and latitudes. As noted earlier, these two patterns are probably causally independent, but are additive in their expression. The first pattern has often been interpreted as a result of changes in the Earth's orbit relative to the Sun ${ }^{19}$. The second pattern may be related to cyclic intervals of decreased solar activity ${ }^{1}$. The most recent glacial phase has been correlated with an extended period of decreased solar activity ${ }^{1}$. Because the preceding two, and probably three, phases had a similar regular occurrence ${ }^{1}$ and a similar short duration of from four to six centuries $^{1,2,6,2,10,20}$, they may also be related to recurrent periods of reduced solar activity. A glacial phase before the Cochrane-Cockburn, the Windermere, which occurred at $10,150-10,810{ }^{14} \mathrm{C}$ years $\mathrm{BP}$, also had a relatively shor't duration of around four to six centuries ${ }^{17}$.

If the two temperature patterns noted here continue, the following changes may be expected: (1) a period of slow cooling to around AD 2450 , followed by an interval of more cooling lasting some 3,000 years, according to the first pattern ${ }^{19}$; and (2) a period of cooling and glaciation around AD 4300 according to the second pattern. A conservative estimate of cooling for the first pattern was made at $3.1^{\circ}$ and $2.7^{\circ} \mathrm{C}$ for latitudes $25^{\circ}$ and $65^{\circ} \mathrm{N}$ (ref. 21). For England, cooling as a result of the second pattern showed a decline of nearly $2.0^{\circ} \mathrm{C}$ from $\mathrm{AD} 1000$ 1300 to the "Little Ice Age"22,23. If cooling of around $3.0^{\circ} \mathrm{C}$ as a result of the first pattern is insufficient to trigger a glacial era, then it is conceivable that the temperature decline of nearly $2 \cdot 0^{\circ} \mathrm{C}$ estimated for mid-latitudes for the second pattern could contribute the cooling necessary for continental glaciation. A possible new glacial era may begin, therefore, somewhere around $\mathrm{AD} 4300$, the next predicted 2,600 year temperature decline, or sooner, if the rapid cooling predicted from the first pattern to occur after AD 2450 is sufficient.

\section{J. R. BRAY}

PO Box 494,

Nelson, New Zealand.

Received May 11; revised July 7, 1970.

${ }^{2}$ Bray, J. R., Nature, 220, 672 (1968)

${ }^{2}$ Bryson, R. A., Wendland, W. M., Ives, J. D., and Andrews, J. T., Aret. Alp. Res., 1, 1 (1969)

${ }^{3}$ Zoller, H., Schindler, C., and Röthlisberger, H., Verh. Naturf. Ges. Basel, y7, 97 (1966).

${ }^{4}$ Mayr, F., Z. Geomorph., 8, 3 (1964).

Ahlmann, H. W., Bowman Memorial Lecture (American Geographical Society, 1953)

Mercer, J. H., Quart. J. Roy. Met. Soc., 93, 528 (1967)

'Yorter, S. C., and Denton, G. H., Amer. J. Sci., 265, 177 (1967).

${ }^{8}$ Miller, C. D., Arct. Alp. Res., 1, 49 (1969).

${ }^{9}$ Stalker, A. M., Bull. Geol. Soc. Amer., 80, 2115 (1969).

${ }^{10}$ Page, N. R., Nature, 219, 694 (1968).

11 Heuberger, H., Eiszeitalter Gegenw., 19, 270 (1968).

${ }^{12}$ Lamb, H. H., Quart. J. Roy. Met. Soc., 90, 382 (1964); 91, 542 (1965).

${ }^{13}$ Costin, A. B., Proc. Seventh Intern. Assoc. Quatern. Res., Boulder, Colorado, Abst. Gen. Sess., $78(1965)$

14 Damon, P. E., Met. Monog., 8, 151 (1968).

${ }^{15}$ Stuver, M., in Radiocarbon Variations and Absolute Chronology (Twelfth Nobel Symposium), 197 (Wiley, New York, 1970).

${ }^{16}$ Schove, D. J., J. Geophys. Res., 60, 127 (1955).

17 Manley, G., Ann. NY Acad. Sci., 95, 162 (1961).

${ }^{18}$ Bray, J. R., Science (in the press).

${ }^{19}$ Kukla, F., Geologie Mijnb., 48, 307 (1969).

${ }^{20}$ Frenzel, B., in Proc. Intern. Symp. Roy. Met. Soc., 124 (Royal Meteorological Society, 1966).

${ }^{21}$ Shaw, D. M., and Donn, W. L., Science, 162, 1270 (1968).

${ }^{22}$ Manley, G., Proc. Roy. Soc., B, 161, 363 (1965).

${ }^{23}$ Lamb, H. H., Palaeogeog. Palaeoclim. Palaeoecol., 1, 13 (1965).

\section{Deformation of Particles during Briquetting}

THE briquetting of small particles usually consists of the application of pressure in controlled conditions so that the individual particles hold together to form a 